\title{
Analisis Ideologi pada Teks Mitos Baris Cina di Desa Adat Renon
}

\author{
Putu Galang Nova Anggara Wijaya*, I Gde Nala Antara \\ Program Studi Sastra Bali, Fakultas Ilmu Budaya, Universitas Udayana \\ [galang.nova@yahoo.com], [nala.antara62@gmail.com] \\ Denpasar, Bali, Indonesia \\ *Corresponding Author
}

\begin{abstract}
This study is entitled "Analisis Ideologi pada Teks Mitos Baris Cina di Desa Adat Renon". This study aims to describe the structure of the teks mitos Baris Cina in Desa Adat Renon and analyzes the ideological meaning contained in it. The theories used in the study are structural theory and mythology theory. The stage of providing data used the field method, assised with interview technique, recording thecnique, note-taking technique, and idiomatic translation technique. The data are analyzed using qualitative method by descriptive-analytic technique. The data are presented using qualitative method by deductive technique. The structure of the teks mitos Baris Cina in Desa Adat Renon contsists of incidents, plot, character and characterization, setting, theme, and moral value. There is a connotation meaning in the teks mitos Baris Cina which then develops into a myth so that the myth is used as a way of life by the people as an ideology. The meaning of ideology contained in it is the institution's guard, obligations, and historical relics.
\end{abstract}

Keywords: Ideology, Myth, and Baris Cina.

\section{Abstrak}

Penelitian ini berjudul "Analisis Ideologi pada Teks Mitos Baris Cina di Desa Adat Renon". Kajian ini bertujuan untuk mendeskripsikan struktur yang membangun teks mitos Baris Cina di Desa Adat Renon, dan menganalisis makna-makna ideologi yang terdapat di dalamnya. Teori yang digunakan pada penelitian ini adalah teori struktural dan teori mitologi. Tahap penyediaan data digunakan metode lapangan, dibantu teknik wawancara, teknik rekam, teknik catat, dan teknik terjemahan idiomatis. Tahap analisis data digunakan metode kualitatif dengan teknik deskriptif analitik. Pada tahap penyajian hasil analisis digunakan metode informal dengan teknik deduktif. Struktur yang membangun teks mitos Baris Cina di Desa Adat Renon, terdiri atas insiden, alur (plot), tokoh dan penokohan, latar (setting), tema, dan amanat. Pada teks mitos Baris Cina terdapat makna konotasi yang kemudian berkembang menjadi mitos, sehingga mitos tersebut dijadikan sebagai pedoman hidup oleh masyarakatnya sebagai sebuah ideologi. Makna ideologi yang terdapat di dalamnya adalah penjaga pranata, kewajiban, dan peninggalan sejarah.

Kata kunci: Ideologi, Mitos, dan Baris Cina

\section{PENDAHULUAN}

Berbicara mengenai sastra lisan, tidak terlepas dari adanya folklore karena folklore adalah kebudayaan tradisional yang diwariskan oleh nenek moyang terdahulu secara terus menerus. Folkore berasal dari dua asal kata yaitu folk dan lore. Folk artinya sekelompok masyarakat sedangkan lore artinya kebudayaan baik lisan atau melalui tanda isyarat. Jadi folklore adalah kebudayaan dari suatu masyarakat yang diwarisi secara turun-menurun baik secara lisan ataupun adanya tanda-tanda isyarat (Danandjaja, 1984: 1-2). Folklore dapat 
dicari melalui kearifan budaya lokal yang salah satu contohnya adalah cerita rakyat (Sutaryanto, 2016: 231).

Salah satu contoh folklore adalah cerita prosa rakyat berbentuk mitos. Menurut Cahyanti (2017: 14) mitos adalah cerita bersimbolik tentang setengah dewa pada jaman dulu yang mengandung pendidikan alam semesta, manusia atau bahkan masyarakat tertentu. Menurut Iswidayanti (2017: 108) mitos dalam dunia mitologi memiliki makna suatu bentukan masyarakat yang berinteraksi jaman dulu kala dari bentuk sejarah yang bersifat kekal.

Di Denpasar terdapat sebuah mitos yang memiliki keunikan tersendiri, tepatnya di Desa Adat Renon yaitu mitos tentang Baris Cina. Dibalik mitos tersebut terdapat sebuah cerita tentang kakak beradik yang sakti mandra guna berperang. Karena mengaku kalah maka I Renggan diperintahkan untuk menjaga Pura Dalem Ped Nusa Penida sebagai Ida Ratu Gede Macaling sedangkan I Renggin dijadikan pelindung Desa di Renon sebagai Ida Ratu Tuan Baris Cina. Keistimewaan dan keunikan teks mitos Baris Cina ini adalah dengan adanya teks mitos ini mampu menumbuhkan kepercayaan terhadap leluhur mereka yang disakralkan keberadaannya dan menciptakan kesenian berupa tari Baris yang berfungsi sebagai pelindung Desa Adat Renon dengan nama tari Baris Cina. Keunikan lain teks mitos Baris Cini ini juga mampu menghasilkan peninggalan berupa prasasti yang disebut dengan prasasti Blanjong.

Teks mengenai mitos Baris Cina memiliki makna yang mengitarinya sehingga memperkuat kesakralan dalam tarian Baris Cina tersebut. Hal itulah yang menyebabkan peneliti mengkaji teks dibalik lahirnya tari Baris Cina di Desa Adat Renon ini sebagai penelitian dalam bidang sastra. Sebelumnya sudah pernah dilakukan penelitian terhadap tari Baris Cina dalam bidang seni tari yang dilakukan oleh Bandem dkk, dengan mengkaji ragam gerak tari Baris Cina, struktur pertunjukan tariannya, dan kostum yang digunakan penari Baris Cina saat melakukan pementasan. Namun, penelitian terhadap cerita dibalik lahirnya tari Baris Cina di Desa Adat Renon, khususnya penelitian terhadap teks mitos tersebut dalam bidang sastra belum pernah dilakukan.

Berdasarkan uraian di atas yang menjadi pembahasan pada penelitian dengan judul "Analisis Ideologi pada Teks Mitos Baris Cina di Desa Adat Renon" ini adalah struktur yang membangun teks mitos tersebut dan makna ideologi yang terkandung di dalam teks mitos Baris Cina.

\section{METODE}

Metode pada penelitian dengan judul "Analisis Ideologi pada Teks Mitos Baris Cina di Desa Adat Renon" ini dibagi menjadi tiga tahapan, yaitu sebagai berikut.

Tahap penyediaan data menggunakan metode lapangan yang dibantu dengan teknik wawancara, teknik catat, dan teknik terjemahan secara idiomatis.

Tahap analisis data menggunakan metode kualitatif dibantu dengan teknik deskriptif analitik. Deskripsi dan analisis artinya menjabarkan, namun tidak hanya menjabarkan tetapi juga memberikan pengertian dan penjelasan secukupnya (Ratna, 2004: 53).

Tahap penyajian hasil analisis menggunakan metode informal. Metode informal adalah cara penyuguhkan melalui kata yang tanpa adanya angka (Ratna, 2004: 50). Metode ini dibantu dengan teknik deduktif. Teknik deduktif digunakan dengan bertolak dari premis yang bersifat umum sehingga menghasilkan kesimpulan yang lebih mengkhusus (Mujianto dkk, 1993: 4).

\section{KERANGKA TEORI}

Karya sastra yang merupakan cerminan manusia pada dasarnya adalah struktur. Struktur ini dibentuk oleh unsur-unsur karya sastra sehingga sastra itu sendiri merupakan hasil yang organik (Jannah dkk, 2018: 2). Analisis struktur karya sastra yaitu cerita fiksi, dapat dikerjakan dengan mendeskripsikan hubungan antarunsur intrinsik fiksi tersebut. Analisis struktural bertujuan untuk menjelaskan sedetail mungkin kedudukan dan hubungan antarberbagai unsur karya sastra yang secara bersamaan memperoleh sebuah kesatuan yang utuh (Nurgiyantoro, 1995: 37). 
Pada teori Barthes, konotasi berhubungan dengan makna ideologi yang disebut dengan mitos dan berfungsi mengungkapkan dan memberikan penjelasan terhadap aturan yang berlaku dalam suatu masyarakat (Asrofah, 2014: 4). Barthes menggunakan teori tanda Saussure sebagai dasar untuk menjelaskan bagimana kita dalam kehidupan sehari-hari diitari oleh konotasi. Konotasi adalah keberlanjutan dari segi petanda (makna) oleh orang yang menggunakan tanda sesuai dengan pandangannya. Konotasi yang sudah menguasai hidup masyarakat banyak akan menjadi sebuah mitos dan mitos akan berkembang menjadi sebuah ideologi bagi masyarakatnya (Hoed, 2014: 17).

Ideologi adalah ilmu dan penggolongan ide dari dalam kepentingan suatu masyarakat dan digunakan sebagai pengetahuan yang diposisikan sebagai hal alami (Johari, 2016: 36). Shadily (1982: 1368) mengemukakan, berdasarkan bentuk, ideologi dibagi menjadi dua yaitu ideologi resmi dan ideologi tak resmi. Ideologi resmi adalah ideologi yang dijadikan sebagai landas tumpu suatau Negara. Berbeda dengan ideologi tak resmi yang disampaikan melalui kisah-kisah atau dongeng sebagai cara menanamkan pendidikan terhadap seseorang.

\section{HASIL DAN PEMBAHASAN}

\section{Struktur Teks Mitos Baris Cina di Desa Adat Renon}

Struktur yang membangun teks mitos Baris Cina di Desa Adat Renon terdiri atas insiden, alur (plot), tokoh dan penokohan, latar (setting), tema, dan amanat.

Insiden adalah kejadian-kejadian atau peristiwa yang terjadi dalam sebuah cerita yang secara keseluruhan sebagai kerangka struktur seluruh cerita (Sukada, 1982: 22). Insiden pada teks mitos Baris Cina terdiri atas delapan insiden. Insiden pertama diawali ketika anak buah Dalem Dukut yang berupa lelembut, senang mengganggu dan menjadikan perempuan cantik sebagai istri sehingga masyarakat menjadi ketakutan. Insiden kedua digambarkan ketika Ki Dukuh Jumpungan mampu mengatasi musibah tersebut dengan bertapa di atas Bukit Nusa Penida. Insiden ketiga adalah ketika I Renggan dan I Renggin memperoleh ilmu karena ketekunannya dalam bertapa semadi. Insiden selanjutnya adalah saat I Renggan membelah lautan Bali dengan perahu milik kakeknya sehingga menyebabkan Padang Bai dan Nusa Penida dibatasi oleh lautan. Insiden lain terlihat ketika munculnya keinginan lain dari I Renggan untuk menabrakkan daratan Bali dengan perahu kakeknya namun diketahui oleh Ida Batara Tohlangkir. Insiden selanjutnya adalah dihadangnya perahu I Renggan bersama anak buahnya oleh pasukan Raja Sri Kesari Warmadewa dibantu I Renggin dan dihempaskan kekuatan angin kencang dari Ida Batara Tohlangkir. Insiden selanjutnya adalah ketika I Renggan bersama anak buahnya kalah, maka diperintahkanlah ia untuk menjaga Pura Dalem Ped Nusa Penida sebagai Ida Ratu Gede Macaling. Insiden terakhir pada teks mitos ini terlihat ketika dijadikannya I Renggin sebagai pelindung di Desa Adat Renon, bermanifestasikan Ida Ratu Tuan Baris Cina.

Menurut Sudiasih (2016: 175) alur (plot) yaitu untaian peristiwa yang memiliki hubungan sebab akibat sehingga menjadi satu kesatuan yang padu. Tahapan alur yang pertama (situation) pada teks mitos Baris Cina ini diawali ketika anak buah Dalem Sawang yang berupa lelembut suka mengganggu dengan menjadikan perempuan cantik sebagai istri sehingga masyarakat menjadi ketakutan. Tahap pemunculan konflik (generating circumstances) terlihat ketika adanya niat jahat I Renggan bersama anak buahnya berupa lelembut untuk membelah lautan Bali dengan menggunakan perahu milik kakeknya. Tahap peningkatan konflik (racing action) muncul ketika adanya niat jahat I Renggan bersama anak buahnya untuk menabrakkan perahu milik kakeknya di daratan Bali yang merupakan tempat kerajaan Raja Sri Kesari Warmadewa yaitu pada Besakih dan Besakih. Tahap klimaks (climax) dari teks mitos ini adalah ketika dihadangnya perahu yang membawa I Renggan bersama anak buanya yaitu para lelembut oleh pasukan Raja Sri Kesari Warmadewa dibantu I Renggan dengan kekuatan angin dari Ida Batara Tohlangkir perahu tersebut berhasil dihempaskan sampai 
ke pantai selatan. Tahap alur terakhir yaitu tahap penyelesaian (denouement) adalah diperintahkannya I Renggan bersama anak buahnya untuk menjaga Pura Dalem Ped Nusa Penida sebagai Ida Ratu Gede Macaling, sedangkan I Renggin dijadikan sebagai pelindung desa sebagai Ida Ratu Tuan Baris Cina.

Tokoh dan penokohan pada dasarnya adalah suatu struktur. Ia memilih bagian fisik dan bagian mental tokoh secara bersamasama membentuk perilaku tokoh yang bersangkutan (Karmini, 2011: 19). Pada teks mitos Baris Cina terdapat tiga jenis tokoh yaitu tokoh utama, tokoh sekunder, dan tokoh pelengkap. Tokoh utama pada teks mitos tersebut adalah I Renggan dan I Renggin. Penokohan tokoh I Renggan digambarkan melalui dimensi psikologis sedangkan penokohan pada tokoh I Renggin digambarkan melalui dimensi sosiologis. Tokoh sekunder pada teks mitos tersebut adalah Ki Dukuh Jumpungan dan wong samar (lelembut). Penokohan pada tokoh Ki Dukuh Jumpungan digambarkan melalui dimensi fisikologis dan sosiologis sedangkan penokohan pada tokoh wong samar (lelembut) digambarkan melalui dimensi sosiologis. Tokoh pelengkap pada teks mitos Baris Cina adalah Ida Batara Tohlangkir dan Raja Sri Kesari Warmadewa. Penokohan tokoh Ida Batara Tohlangkir digambarkan melalui dimensi fisikologis sedangkan penokohan pada tokoh Raja Sri Kesari Warmadewa digambarkan melalui dimensi fisikologis dan sosiologis.

Latar atau setting yang disebut juga sebagai landasan bertumpu, yang mengacu pada pengertian tempat, hubungan waktu, dan lingkungan sosial tempat terjadinya peristiwa-peristiwa yang diceritakan. (Nurgiyantoro, 1995: 216). Latar dalam karya sastra tidak hanya pada tempat-tempat tertentu atau yang bersifat fisik semata. Latar bisa berwujud adat istiadat, kepercayaan, dan nilai-nilai yang berlaku di tempat yang bersangkutan (Sari, 2019: 68). Penggambaran latar pada teks mitos Baris Cina dibagi menjadi tiga unsur latar yaitu latar tempat, latar waktu, dan latar sosial. Latar tempat pada teks mitos Baris Cina tersebut misalnya ring Nusa Penida, $k a$ madyapada, ring Pucak Bukit Nusa Penida, ring madyaning samudra, Padang Bai lan Nusa Penida, ring tanah Bali, ring segara kidul, ring Pucak Mundi, Dalem Ped, dan ring Pura Kahyangan Desa Adat Renon. Latar waktu yang terlihat pada teks mitos tersebut misalnya rahina anu, warsa $913 \mathrm{M}$ utawi 835 Caka, dan tilem sasih kalima jantos kasanga. Latar sosial yang terlihat misalnya kebiasaan masyarakat dan kepercayaan masyarakat.

Tema adalah pemikiran dasar suatu cerita, ia selalu berkata dengan berbagai pengelaman kehidupan seperti masalah cerita, rindu, takut, dan lain sebagainya (Delvia, 2017: 256). Tema menjadi sorotan utama bagi seorang pengarang karya sastra (Karmini, 2011: 45). Tema yang terlukiskan pada teks mitos Baris Cina di Desa Adat Renon ini adalah tema mistis karena dari awal cerita, pertengahan cerita, klimaks, hingga pada akhir cerita pada teks mitos ini bercerita tentang unsur-unsur mistis yang dialami oleh tokoh.

Amanat disebut dengan moral. Moral merupakan sesuatu yang ingin diingatkan oleh pengarang kepada pembaca, merupakan makna yang terkandung dalam sebuah karya sastra (Nurgiyantoro, 1995: 320). Amanat yang terdapat pada teks mitos Baris Cina ini adalah sebagai makhluk yang berbudi pekerti luhur hendaknya kita selalu taat menjalankan upacara pembersihan desa yang disebut upacara ngaturang hidangan. Hal itu dilakukan guna menghindari masyarakat di Desa Adat Renon dari grubug yang ditimbulkan oleh Ida Ratu Gede Macaling bersama anak buahnya yang berupa lelembut.

\section{Makna Ideologi Teks Mitos Baris Cina di Desa Adat Renon}

Makna ideologi yang terdapat dalam teks mitos Baris Cina adalah makna tak resmi seperti penjaga pranata, kewajiban, dan peninggalan sejarah. Ketiga makna ideologi tersebut adalah sebagai berikut.

Pranata adalah konstruksi dari seperangkat fungsi-fungsi dan aturan-aturan tingkah laku yang terstruktur (Narwoko dan Suyanto, 2010: 216). Aturan-aturan tersebut apabila diwujudkan oleh anggota masyarakat secara berkelanjutan akan menghasilkan komunikasi yang positif atau baik diantara 
anggota masyarakat yang pada gilirannya akan berdampak pada masyarakat yang lebih luas lagi (Wartono, 2015: 1062). Dalam teks mitos Baris Cina yang menjadi penjaga pranata adalah Ida Ratu Tuan Baris Cina sebagai manifestasi dari I Renggin. Makna ideologi tersebut terbentuk akibat dari adanya sebuah konsep yaitu "sungsungan" bagi masyarakat Renon terhadap Baris Cina.

Selain tari Baris Cina yang dijadikan sebagai ideologi berupa penjaga pranata oleh masyarakat Renon, terdapat ideologi kewajiban yang berkaitan dengan tari Baris Cina tersebut. Menurut Kamus Besar Bahasa Indonesia (2005: 1266), kewajiban adalah sesuatu yang diwajibkan atau sesuatu yang harus dilaksanakan. Adapun yang menjadi kewajiban bagi masyarakat Desa Adat Renon adalah melaksanakan upacara ngaturang hidangan. Makna ideologi tersebut terbentuk akibat dari adanya konsep "kewajiban" yang harus dilakukan masyarakat di Desa Adat Renon untuk menghaturkan upacara ngaturang hidangan, setiap tilem sasih kalima sampai sasih kasanga. Selain mengandung konsep kewajiban, upacara ngaturang hidangan di Desa Adat Renon juga mengandung konsep "yadnya". Menurut Renawati (2019: 373) sebagai rasa terima kasihnya akan segala anugerah dari Tuhan maka umat Hindu di Bali melakukan upacara suci sebagai ucapan terima kasih yang disebut yadnya. Sukrawati (2017: 86-87) mengemukakan yadnya berarti korban suci atau persembahan suci berdasarkan cinta kasih. Walaupun ajaran yadnya secara umum merupakan bagian dari ajaran agama Hindu tetapi dalam praktiknya di lapangan sering kali terdapat perbedaan antara daerah yang satu dengan daerah yang lainnya.

Selain makna ideologi sebagai penjaga pranata dan kewajiban, pada teks mitos Baris Cina terdapat makna peninggalan sejarah. Menurut Suratno (2016: 14) sejarah adalah ilmu yang berisi kisah perbuatan manusia pada masa dulu dan masa sekarang. Unsur pokok sejarah ada tiga yaitu manusia, ruang, dan waktu. Wartha (2016: 190) mengemukakan peninggalan yang berfungsi sebagai simbol pemujaan terhadap Tuhan Yang Maha Esa dalam upacara agama. Adanya ideologi peninggalan sejarah, bersumber pada konsep dari masyarakat di Desa Adat Renon terhadap prasasti Blanjong, yaitu sebagai sebuah "keajaiban".

\section{SIMPULAN}

Berdasarkan uraian di atas, penelitian dengan judul "Analisis Ideologi pada Teks Mitos Baris Cina di Desa Adat Renon" ini, dapat ditarik kesimpulan sebagai berikut.

Struktur yang membangun teks mitos Baris Cina ini terdiri atas insiden, alur (plot), tokoh dan penokohan, latar (setting), tema, dan amanat yang memiliki hubungan antarunsur di dalamnya sehingga menjadi satu kesatuan yang utuh dalam sebuah karya sastra.

Makna ideologi yang terdapat pada teks mitos Baris Cina terdiri atas tiga ideologi yaitu penjaga pranata, kewajiban, dan peninggalan sejarah. Ketiga ideologi tersebut berasal dari adanya konsep, yang akan berkembang menjadi mitos, dan mitos pada akhrinya akan menghasilkan ideologi yang mampu dimaknai oleh masyarakatnya. Ketiga ideologi tersebut memiliki kaitan dengan struktur yang membangun teks mitos Baris Cina di Desa Adat Renon, sebagai tanda adanya hubungan erat antara struktur yang membangun teks mitos Baris Cina dengan makna ideologi yang mengitarinya.

\section{REFERENSI}

Asrofah. 2014. Semiotika Mitos Roland Barthes dalam Analisis Iklan di Media Massa. Sasindo Vol. 2 No.1. Semarang: Universitas PGRI.

Barthes, Roland. 2009. Mitologi (terj. Nurhadi dan A. Sihabul Millah). Yogyakarta: Kreasi Wacana.

Cahyanti, Ika, Sukatman, dan Furoidatul Husniah. 2017. Mitos dalam Ritual Masyarakat Mandura di Kecamatan Gending Kabupaten Probolonggo. Jukasi Vol.IV No.1: 13-19. Jember: Universitas Jember.

Danandjaja, James. 1984. Folklor Indonesia (Ilmu Gosip, Dongeng, dan Lain-lain). Jakarta: PT. Grafis Pers. 
Delvia, Ni Putu Gek Anna, L. P. Puspawati, dan I Gde Nala Antara. 2017. Teks Mitos Tapakan Barong Bhatara Sakti Nawa Sanga di Kahyangan Jagat Luhur Natar Sari: Analisis Struktur dan Fungsi. Humanis Vol.18.1. Denpasar: Fakultas Ilmu Budaya Universitas Udayana.

Hoed, Benny H. 2014. Semiotik \& Dinamika Sosial Budaya. Depok: Komunitas Bambu.

Iswidayanti, Sri. 2017. Fungsi Mitos dalam Kehidupan Sosial Budaya Masyarakat Pendukungnya. Harmonia Vol.VIII No.2. Semarang: Universitas Negeri Semarang.

Jannah, Miftahul, Edi Suyanto, dan Ali Mustofa. 2018. Pemahaman Struktur Cerpen Kenang-kenangan Seorang Wanita Pemalu Karya Rendra di SMA. Kata (Bahasa, Sastra, dan Pembelajarannya). Lampung: Universitas Lampung.

Johari, Arief. 2016. Representasi Mitos dan Makna pada Visual Lambang Daerah. Ritme Vol.2 No.1. Bandung: Universitas Pendidikan Indonesia.

Karmini, Ni Nyoman. 2011. Teori Pengkajian Prosa Fiksi dan Drama. Tabanan: Saraswati Institut Pers.

Mujianto, Gigit, Djoko Asihono, Hari Sunaryo dkk. 2010. Bahasa Indonesia untuk Kerangka Ilmiah: Makalah, Skripsi, Tesis, Disertasi (Edisi Revisi). UMM Press.

Narwoko, J. Dwi, dan Bagong Suyanto. 2010. Sosiologi Teks Pengantar dan Terapan. Jakarta: Kencana Prenada Media Group.

Nurgiyantoro, Burhan. 1995. Teori Pengkajian Fiksi. Yogyakarta: Gadjah Mada University Press.
Ratna, Nyoman Kutha. 2004. Teori, Metode, dan Teknik Penelitian Sastra dari Strukturalisme hingga Perspektif Wacana Naratif. Yogyakarta: Pustaka Pelajar.

Renawati, Pande Wayan. 2019. Implementasi Upacara Manusa Yadnya dalam Naskah Drama Kahuripan (Perspektif Teologi Hindu). Mudra Jurnal Seni Budaya Vol.34 No.3. Denpasar: Program Pascasarjana IHDN.

Sari, Ni Kadek Surya Dewi, Tjok Istri Agung Mulyawati, dan I Ketut Ngurah Sulibra. 2018. Teks Mitos Tirta Selaka di Pura Kereban Langit Sading Kecamatan Mengwi: Analisis Struktur dan Fungsi. Humanis Vol.22.2. Denpasar: Fakultas Ilmu Budaya Universitas Udayana.

Sari, Ni Putu Mita Manika, I Ketut Ngurah Sulibra, dan I Nyoman Duana Sutika. 2019. Mitos Bunut Bolong di Desa Manggissari Kecamatan Pekutatan: Analisis Struktur dan Makna. Humanis Vol.23.1. Denpasar: Fakultas Ilmu Budaya Universitas Udayana.

Shadily, Hassan dkk. 1982. Ensiklopedi Indonesia Jilid 3. Jakarta: Ichtiar BaruVan Hoeve.

Sudiasih, Ni Putu. 2016. Mitos di Nusa Penida: Analisis Struktur, Fungsi, dan Makna. Humanis Vol.15.2. Denpasar: Fakultas Ilmu Budaya Universitas Udayana.

Sukada, I Made. 1982. Unsur Insiden dan Perwatakan dalam Fiksi. Tahun I No.2. Denpasar: Majalah Widya Pustaka Fakultas Sastra Universitas Udayana.

Sukrawati, Ni Made. 2017. Nilai Didaktsis Upacara Pacaruan Sasih Kaenem di Pura Pasek Ngukuhin, Desa Pakraman Tonja, Kota Denpasar. Dharmasmrti Vol.XVII No. 02. Denpasar: Universitas Hindu Indonesia. 
Suratno. 2016. Meningkatkan Pemahaman Konsep Peninggalan Sejarah Hindu di Indonesia Melalui Strategi Pembelajaran Inkuiri Sosial di Kelas $V$ SD 2 Buga Kabupaten Tolitoli. Kreatif Tadulako Vol.4 No.10. Fakultas Keguruan dan Ilmu Pendidikan Universitas Tadulako.

Sutaryanto. 2016. Folklor dan Peranannya dalam Menumbuhkembangkan Multikultural Siswa Sekolah Dasar. Neliti Vol.1. Madiun: Institut Keguruan dan Ilmu Pendidikan PGRI.

Tim Redaksi. 2005. Kamus Besar Bahasa Indonesia (Edisi Ketiga). Jakarta: Pusat Bahasa Departemen Pendidikan Nasional.

Wartha, Ida Bagus Nyoman. 2016. Manfaat Penting "Benda Cagar Budaya" sebagai Peninggalan Sejarah/ Arkeologi untuk Kepentingan Agama, Sosial Budaya, Ekonomi Budaya, Pendidikan dan Ilmu Pengetahuan (Studi Kajian Budaya). Santiaji Pendidikan Vol.6 No.2. Denpasar: Universitas Saraswati.

Wartono. 2015. Pranata Sosial Keagamaan dalam Lingkungan Keluarga Muslim. Edukasi Islami Vol. 04. Bogor: Sekolah Tinggi Agama Islam Hidayah. 